\title{
Egzistencijalistički nadahnuta lirika u Hrvatskoj, Sloveniji i Mađarskoj
}

\author{
Orsolya Kálecz-Simon \\ Sveučilište Eötvös Loránd u Budimpešti, Filozofski fakultet, Katedra za \\ slavističku filologiju, Budapest, Múzeum krt.4/D, kaleczo@gmail.com
}

\begin{abstract}
V petdesetih in šestdesetih letih 20. stoletja se je v srednjeevropskem pesništvu pojavila zelo močna literarna smer, ki je črpala iz različnih literarnih in filozofskih pogledov Camusa, Sartra in drugih. Medtem ko so zahodni eksistencialisti poudarjali pomen družbene angažiranosti, so se njihovi vzhodni kolegi osredotočali predvsem na ontološka vprašanja in stremeli po literarnem okolju brez vplivov ideologij. Razprava predstavlja liriko treh pesnikov - Edvarda Kocbeka (Slovenija), Slavka Mihalića (Hrvaška) in Jánosa Pilinszkyja (Madžarska) - ter izpostavlja njihove stične točke: ontološko-individualistične teme, izoliranost lirskega subjekta, predmetnost in težnja po depersonalizaciji, svobodni verz ter pesniški jezik, podoben živemu jeziku.
\end{abstract}

In the 1950 s and 1960 s, a very influential type of poetry was born in Central Europe that owes a lot to Camus, Sartre et al. While Western existentialists emphasized the need for social engagement, their Eastern colleagues concentrated on ontological questions and tried to create a literary environment isolated from ideological influences. This paper discusses the poetry of Edvard Kocbek (Slovenia), Slavko Mihalić (Croatia) and János Pilinszky (Hungary), whose most important common points are their ontological-individualistic topics, isolation of the lyric subject, the objectivist and depersonalizing tendencies, free verse and a poetic manner of speaking that is very close to live speech.

Ključne besede: eksistencializem, pesništvo, srednja Evropa, Edvard Kocbek, Slavko Mihalić, János Pilinszky

Key words: existentialism, poetry, Central Europe, Edvard Kocbek, Slavko Mihalić, János Pilinszky

U ovom članku želimo predstaviti egzistencijalističku liriku kao poseban tip egzistencijalističko nadahnute književnosti koja, osim unikatnih pjesničkih pristupa, nudi i sasvim originalnu interpretaciju egzistencijalizma. 
Egzistencijalizam je zadnja stanica moderne koja narušava većinu filozofskih pojmova koji dolaze iz moderniteta, tvrdeći da zapravo i oni nose iluzije religije: jedino subjekt, i naravno, vjera u jezik ostaju netaknuti.

Smisao egzistencijalističke revolucije je spoznaja da je svijet kontingentan. Ovo s jedne strane ima epistemološku konzekvenciju - naime, da se svijet ne može upoznati jer se ne može u potpunosti opisati sredstvima modernističke fillozofije i znanosti (Kálecz 2008: 5-29), a s druge strane ima i ontološku konzekvenciju - tj. da svijet i događaji u njemu nemaju nikakav transcendentni uzrok ili objašnjenje (Sartre 2006: 566). Život u ovom svijetu pun je tuge, muke i boli, ali naše patnje lišene su već i nade u katarzu jer nemaju nikakvog razloga niti smisla - čovjek stoji sam samcat usred besmislenog i neprijateljskog svijeta (Kálecz 2008: 49-50).

U vezi života u apsurdnom svijetu može se postaviti niz pitanja: treba li se suočiti s tom činjenicom, može li se uopće živjeti u takvom svijetu, te može li postojati ikakav moral pod tim uvjetima. Egzistencijalisti kao Sartre, a pogotovo Camus, smatraju da je naša moralna obaveza suočiti se s činjenicom apsurdnosti svijeta i života, i, koliko je moguće, boriti se protiv njega (Kálecz 2008: 35-41).

Sartre, međutim, tvrdi da je čovjek također kontingentan, i najveća mu je motivacija da daje smisao svome postojanju. Zbog toga traži kontakt s Drugim, zbog toga želi ostvariti svoju slobodu, tražeći autentični način življenja i mogućnost proširenja slobode drugih (Sartre 2006: 726).

U eseju Egzistencijalizam je humanizam Sartre dokazuje: za ostvarenje naše slobode nužan je preduvjet ostvarenje sloboda drugih ljudi. Sartre (1946: 726) time sugerira da radi potpunog samoostvarenja čovjek mora igrati i političku ulogu, i to u ljevičarskom ruhu. Štoviše, to se odnosi i na književno djelovanje: Sartre je u djelu Što je književnost najavio i potrebu za angažiranom književnošću. Tvrdi da je pisanje proze zapravo vrsta djelovanja, znači da je njegov cilj promijeniti neku određenu situaciju (Sartre 1969: 40-42). Sartre smatra da neangažirana književnost zapravo i ne postoji te da pisac uvijek treba uzimati u obzir kakav će utjecaj njegovo djelo imati na svijet i na ostale ljude (Sartre 1969: 44).

Možemo dakle vidjeti da u Zapadnoj Europi egzistencijalizam nije stao kod konstatacije apsurdnosti svijeta i definiranja čovjekove egzistencije, nego je prešao dalje od toga, prema ekstenzivnom djelovanju. U skladu s time, egzistencijalisti su bili izuzetno aktivni, primjerice oni su organizirali ljevičarski pokret RDR (Aronson 2004: 103-105), sam Sartre je također bio suputnik Komunističke partije između 1952-56 (Pollmann 1974: 64), a i razvoj književnosti slijedio je taj put.

Valja spomenuti da je u egzistencijalističkim djelima već ispočetka bio prisutan jedan društvenokritički ton: na primjer, u Sartreovoj knjizi Mučnina, osim ontoloških primjedbi, kritizira se građansko društvo zbog negiranja apsurdnosti svijeta i, s time, potopljenja u inautentični život.

Nakon drugog svjetskog rata ova kritika postaje izrazitija i konkretnija: pisci egzistencijalisti oštro i jasno kritiziraju negativne pojave novog društva kao što su industrijalizacija, otuđenje, komformizam, te suvremene političke 
pojave kao što je hladni rat, a pored toga prikazuju se i dileme individue koja se osjeća nemoćna u velikoj i složenoj mreži društva (Keefe 1974: 213-234).

U slovenskoj književnosti egzistencijalistička misao se pojavila između dva svjetskog rata, zahvaljujući križarima. Križarski pokret se pojavio paralelno s drugim sličnim pokretima u Europi, kao reakcija na socijalnu, kulturalnu i duhovnu bijedu nakon prvog svjetskog rata (Kralj 2005: 5-7). U početku su tražili odgovore na spiritualnom području, u obnovi kršćanske vjere, ali su uskoro prepoznali i potrebu preobrazbe društva, i surađivali su s različitim socijalističkim organizacijama (Kralj 2005: 8).

Jedan od vodećih ličnosti ovog pokreta je bio upravo Edvard Kocbek koji pored svog uredničkog i organizatorskog rada imao je značajan utjecaj i na idejnu usmjerenost cijelog pokreta. Početkom 1930-ih godina Kocbek je upoznao i francuski personalizam u kojemu je pronašao potvrđivanje vlastitog idejnog stajališta, i odgovore na svoje aktualne dileme (Kralj 2005: 16). Pored toga je proučavao i kršćanski egzistencijalizam, pogotovo Kierkegaardovu djelatnost, koje je u svojim esejima i predstavio književno osvještenoj publici svoje domovine (Pogačnik i Zadravec 1973: 500-503). Ali Kocbek je postao pionir i sa svojom zbirkom pjesama Zemlja (1934) koja je postala uzor za tematiziranje ontoloških pitanja lirskim sredstvima.

Ovi počeci omogućili su i širu književnu recepciju egzistencijalističkih ideja do čega je došlo tek nakon drugog svjetskog rata i poslije totalitarnog razdoblja jugoslavenskog socijalizma. U toj je recepciji Kocbek također imao izuzetno važnu ulogu objavivši zbirku novela Strah in pogum (1951), te zbirke pjesama u 1960-im godinama. Kocbekova je djelatnost vjerojatno imala velik udio u „egzistencijalističkom obratu“ slovenske književnosti u 1950-im i u 1960-im godinama, te je snažno inspirirala poslijeratnu generaciju književnika (Izvor datuma: Pogačnik i Zadravec 1973: 500-503 i Pogačnik i Zadravec 1973: 499-559).

Hrvatski časopis Krugovi pojavio se 1952., nakon popuštanja totalitarističke diktature, s namjerom da se uspostavi kontinuitet s tradicijom i sa suvremenim međunarodnim književnim životom (Milanja 2003: 56). Taj časopis se sastojao od više „krugova“" različitih koncepcija; najvažnije su im zajedničke crte bile odbijanje estetske diktature i stilskih normi socrealističke koncepcije, i namjera traženja novih poetika (Detoni Dujmić 1995: 89).

Kod Mađara egzistencijalna misao u književnosti najprije se pojavila u časopisu Újhold (1946-1948) čiji su autori htjeli prekinuti s književnom koncepcijom ranijih generacija koja je naglašavala društvenu misiju i kolektivnu orijentaciju. Ključne riječi njihove koncepcije su bile: filozofska, misaona tematika, međunarodni obzor, visoki estetski kriteriji na tragovima mađarske klasične moderne (Lengyel 1946).

Premda ga je totalitarna vlast zabranila tek nakon sedmog broja, Újhold je uspio očuvati kontinuitet mađarske književnosti i tijekom godina totalitarne diktature, te formirati jedan vrlo važan tip poratne mađarske lirike koji je 
utjecajan i danas. Zapravo, ovaj časopis omogućuje da se u potpunosti razvije druga moderna u mađarskoj lirici (Kulcsár Szabó 1993: 15).

Časopisi Krugovi i Újhold očito su imali slične ambicije: htjeli su stvoriti autonomnu sferu neovisnog književnog diskursa u kojoj su vladali estetski, a ne politički kriteriji. Pored toga, htjeli su izgraditi nov odnos prema tradiciji, tj. s autorima prve moderne.

Osim svjesne kritičke djelatnosti (o tome vidi članke Ottóa Majora, primjerice: (Major 1946); (Major 1948), te (Detoni Dujmić 1995: 90-93)), ti su časopisi bili izuzetno značajni u književnoj povijesti svojih naroda jer su pokušali nadoknaditi zaostalost narodne književnosti kritičkim predstavljanjem zapadnih književnih djela i objavljivanjem prijevoda. Vrlo je važan utjecaj nove stvarnosti (Eliot i Pound), ali oni su ,importirali“ i egzistencijalizam koji je u hrvatskoj književnosti postao izuzetno važan, a spominjao se već i u mađarskom Újholdu (na primjer: (Somlyó 1947, Szabolcsi 1946), osobito u kritici zbirke pjesnikinje Ágnes Nemes Nagy).

Ovo su dakle bili uvjeti koji su omogućili da se u svima trima zemljama razvije vrlo utjecajan tip egzistencijalističke lirike, što ima bogatu literaturu u sve troje zemalja. Vodeće ličnosti tih književnih tendencija bili su Edvard Kocbek (1904-1981), Slavko Mihalić (1928-2007) i János Pilinszky (1921-1981).

Prema slovenskim povijesničarima književnosti Jože Pogačniku i Francu Zadravecu, Edvard Kocbek je krenuo od ekspresionističke tradicije (Pogačnik i Zadravec 1973: 502), ali je ostvario pjesnički program idealističke nove stvarnosti (Pogačnik i Zadravec 1973: 501). Međutim mnogo stručnjaka skreće pozornost i na to da je ontološka tematika već od početka imala ključnu ulogu u Kocbekovom lirskom univerzumu. ${ }^{1}$

U generaciji krugovaških pjesnika Cvjetko Milanja razlikuje dva osnovna lirska modela - jedan od njih je lirika Slavka Mihalića koja je idejno pjesništvo pod utjecajima egzistencijalista; pretežito je semantički orijentirana, a na jezičnoj sferi je asketskija, i dolazi do adheziranosti subjekta (Milanja 2003: 15).

Što se mađarske književnosti tiče, prema klasifikaciji Ernőa Kulcsára Szabóa, u 1960-im godinama su se formirala tri osnovna tipa lirike. Jedan od njih je bio lirika depersonalizacijskog-hermetičkog tipa (Kulcsár Szabó 1993: 55), koja je bila vjerojatno najutjecajnija; model te vrste lirike je pjesništvo Jánosa Pilinszkog.

I same književnopovijesne klasifikacije ukazuju na činjenicu da ti pjesnici imaju jako slično mjesto u pjesništvu svojih naroda: najvažnije su im dodirne točke uvođenje pjesničkog pristupa nove stvarnosti i egzistencijalistička tematika.

Tijekom svojih istraživanja ustanovili smo da možemo naći mnogo zajedničkih crta i među tim pjesnicima i među tipovima lirike koju reprezentiraju, tako

${ }^{1}$ Primjerice Hribar (2002: 15-34), Paternu (1999: 55), Svetina (2010: 31). 
da s pravom možemo govoriti o njima kao predstavnicima srednjoeuropske egzistencijalističke lirike. No prije nego što detaljno prikažem rezultate svojih istraživanja, vratimo se malo na prethodnu temu.

Dok je u Zapadnoj Europi ova vrsta književnosti imala koncepciju s društvenom misijom, te se pridružila kolektivističkim političkim tendecijama, $u$ našim zemljama egzistencijalističke ideje postale su sredstva upravo za pasivnu oporbu protiv kolektivističkih ideja.

Ove pjesme, naime, nisu tematizirale društvena pitanja koja su proizašla iz egzistencijalističkoga pristupa, nego su bile prvotno ontološki usmjerene, te su istraživale univerzalne karakteristike bitka. Ovaj izbor teme služio je kao tiha pobuna protiv nametnutih estetskih ideja, te je - predstavljanjem tmurne i tjeskobne sredine gdje lirski subjekt mora preživljavati - omogućio čak i prikrivenu kritiku aktualnih uvjeta.

Za razliku od svojih zapadnoeuropskih istomišljenika, srednjoeuropski egzistencijalistički nadahnuti pjesnici ne ištu kolektivno rješenje, nego konflikte koji proizlaze iz suočavanja s bitkom pokušavaju razriješiti na individualnoj razini, ili se okreću transcendenciji. Zanimljivo je da - unatoč tome da se radilo o pravom angažiranom intelektualcu koji je bio osjetljiv na društvena pitanja, te u svojim mlađim godinama aktivno sudjelovao u javnom životu svoga naroda - ova perspektiva dominira i u lirici Edvarda Kocbeka.

Na književnopovijesnoj razini, upravo su egzistencijalističke ideje omogućile raskid s nametnutim utilitarističkim estetskim vrijednostima, te su služile kao osnova za izgradnju samostalne književnosti koja više nije utilitarističko sredstvo za prijenos ideja, nego njome upravljaju samostalna estetska načela. To možemo primjetiti u Hrvatskoj i u Mađarskoj, ali i u Sloveniji gdje je upravo Kocbekova zbirka novela Strah in pogum označila kraj soc-realističkog razdoblja i dolazak nove književne ere.

Osim drugačije književnopovijesne uloge vrijedi naglasiti i jednu, naizgled trivijalnu razliku: dok su zapadni egzistencijalistički autori pisali pretežito romane i drame, u Srednjoj Europi se egzistencijalistička misao javila prije svega u lirici.

Ova vrlo jednostavna primjedba dobija poseban značaj ako uzmemo u obzir da je Sartre, otac egzistencijalizma, smatrao da poezija nije prikladna za misiju egzistencijalista. U svojoj knjizi Što je književnost? piše kako pjesnička djela nemaju referenciju u stvarnosti jer pjesnici ne upotrebljavaju riječi kao znakove nego kao predmete - skupove značenja. Pjesnik, tvrdi Sartre, ne prikazuje stvarnost, nego stvara novu, paralelnu stvarnost čiji elementi imaju smisla jedino u odnosu jedan prema drugom (Sartre 1969: 28-30). Za razliku od pjesništva, proza se već smatra referencijalnom, te zapravo čini jedan tip djelovanja (Sartre 1969: 40-42). Ovo Sartreovo razlikovanje referencijalnih i nereferencijalnih tekstova liči na ideje predstavnika novog kriticizma (Ivor Armstrong Richards, a kasnije i drugi). Oni također razlikuju tekstove po referencijalnosti, ali prema njima nijedan književni tekst nije referencijalan - za razliku od neknjiževnih tekstova. I iz Sartreove teorije književnosti i iz činje- 
nice da se ni sam nije bavio lirikom, možemo zaključiti da liriku nije smatrao sposobnom ni za prikazivanje ontološke strukture svijeta, ni za analiziranje moralnih konzekvencija egzistencijalizma.

S pravom možemo dakle postaviti pitanje: je li egzistencijalistička lirika uopće moguća? Činjenice nam zorno prikazuju da jest. Točna je primjedba da su te pjesme dio paralelne stvarnosti, ali ti ,riječ-predmeti“ prikazuju i ujedno pozivaju pozornost na ontološka svojstva originalne stvarnosti. (A, dodajmo, djelomice i ta razlika objašnjava posebne pristupe i motiviranost srednjoeuropske egzistencijalističke lirike.)

Pogledajmo sada kako se ostvaruje ontološka motivacija tih pjesama. To znači se lirski subjekt okreće prema svom bitku, uspostavlja stanovit odnos s njim i pokušava analizirati taj bitak, tražeći njegove granice. Ista crta bila je prisutna u ranijim Sartreovim romanima gdje je subjekt - autorefleksijom - također nastojao pronaći vlastite granice (npr. Mučnina, Djetinjstvo jednog vođe).

Najvažnije sredstvo koje omogućuje da se u okvirima subjektivnog lirskog Žanra govori o ontološkoj problematici je depersonalizacija. ${ }^{2}$ Depersonalizacija - unatoč mišljenjima drugih stručnjaka ${ }^{3}$ - nije znak dezintegracije subjekta, nego nužan postupak prikazivanja tih apstraktnih tema. I, kao što smo vidjeli na početku članka, u egzistencijalističkoj filozofiji još nije došlo do dezintegracije subjekta - u biti, to je bio jedini od modernističkih koncepata koji je ostao netaknut. Ovo znači da, umjesto intimnih ispovijedi i mnoštva detalja, o lirskom subjektu saznajemo jako malo individualnih podataka. On često djeluje kao emocionalno udaljeni govornik, koji naizgled hladno i objektivno promatra svoj bitak i svoj položaj u svijetu. Lirski subjekt i njegova perspektiva pretvara se u metodološki okvir koji omogućuje tematiziranje općeljudskih ontoloških pitanja ili dispozicija u lirskim pjesmama. Ove pjesme su možda najtipičniji primjeri ovih postupaka: Edvard Kocbek: Tema [Tama] (te zbirke Zemlja, Groza i Poročilo [Izvješće]); Slavko Mihalić: Pjesma osuđenika na smrt (te zbirke Komorna muzika, Put u nepostojanje, Početak zaborava i Darežljivo progonstvo); János Pilinszky: Tilos csillagon [Na zabranjenoj zvijezdi] (sve zbirke).

U ovom tipu lirike je prisutnost lirskog subjekta izuzetno naglašena. Svaki - semantički ili sintaktički - element koji se nalazi u pjesmi podređen je njemu, te jedino zato ima smisla jer nešto otkriva o unutrašnjem svijetu subjekta. Najbolji primjeri tih postupaka jesu „egzistencijalistički pejzaži“ tih autora koji su ujedno i eklatantni primjeri upotrebljavanja lirskih sredstava nove stvarnosti: Kocbekova pjesma Deček na drvesu [Dečko na drvetu], Mihalićeva

\footnotetext{
${ }^{2}$ Osnovnu misao da je Pilinszkyjevo pjesništvo depersonalizirano preuzela sam od Sándora Radnótija (Radnóti 1981: 113-114), ali, unatoč Radnótijevom mišljenju koji tvrdi da su Pilinszkyjeve tendencije depersonaliziranja rezultat susreta sa filozofijom Simonea Weila, ja sam dokazala da je depersonalizacija od početka bila prisutna u Pilinszkyjevom pjesništvu, i da je nužan preduvjet tematiziranja ontoloških pitanja. O tome vidi (Kálecz 2009: 19). U citiranom radu sam također dokazala da su tendencije depersonaliziranja prisutne i kod Slavka Mihalića.

${ }^{3}$ Primjerice Kulcsár Szabó (1993: 36).
} 
pjesma Proljeće bez namjere i Pilinszkyjev Öszi vázlat [Jesenji pejzaž]. Ali te karakteristike tipične su i za sve gore navedene zbirke pjesama tih autora.

Ukoliko pjesma ima i referencijalne aspekte, ta referencijalnost je uvijek podređena predstavljanju određenih ontoloških uvjeta, kao primjerice u Kocbekovim pjesmama Igra, Dijalektika i Mikrofon v zidu [Mikrofon u zidu], ili Pilinszkyjevom ciklusu o koncentracijskim logorima u zbirci Harmadnapon [Tré́ega dana].

Drugi je važan postupak tih pjesnika prikazivanje graničnih situacija - tj. prikazivanje onih ontoloških situacija u kojima je subjekt prisiljen suočiti se s granicama svoga bića. Ishodište analize bitka je u svakom slučaju jedna pomno prezentirana granična situacija.

Prvo, sva trojica pjesnika rado tematiziraju smrt i suočavanje sa smrtnošću. $\mathrm{U}$ njihovim pjesmama smrt ima dvojnu narav. S jedne strane, smrt izaziva tjeskobu i strah, koja su esencijalna svojstva ljudskog postojanja (Slavko Mihalić: Ne nadaj se; János Pilinszky: Vesztőhely télen [Stratište zimi]; Edvard Kocbek: Odprta so vsa vrata [Sva su vrata otvorena]). Ali smrt u Mihalićevim i Pilinszkyjevim pjesmama je ujednom i mogućnost da se lirski subjekt riješi ograničenja bitka koja ga sputavaju (Slavko Mihalić: Bih da se; János Pilinszky: Éjféli fürdés [Ponoćno kupanje]). ${ }^{4}$ Ovaj način prikazivanja, kao što je i dvojna narav smrti, prisutan je i u Kocbekovoj lirici (Edvard Kocbek: Bojazen [Strah]). (O tome vidi Novak Popov 2003: 164-171.)

Druga važna granična situacija koja se također često javlja u tim djelima je susret s Drugim. U svijetu Mihalićeve rane lirike, lirski subjekt je potpuno sam u svome univerzumu; potpuno je otuđen od svih drugih, i zajednički platform koji bi omogućio uspostavljanje bilo kakva kontakta s drugima uopće ne postoji (Pristajanja; Pjesma osuđenika na smrt). U Pilinszkyjevoj lirici prava intimnost i jedinstvo s Drugim nije moguća; pokušaji približavanja gotovo su uvijek neuspješni i uglavnom donose bol (Trapéz és korlát [Trapeza i ograda]; Ne félj [Nemoj se bojati]) (Kálecz 2009: 30). Ovaj tip ljubavne lirike pronalazimo i kod Edvarda Kocbeka (Ti si skritost za moje oči [Ti si tajna mojih $o c ̌ i j u$ ], $O b a$ ), ali u njegovoj kasnoj lirici, zbog revalorizacije mjesta ljubavi u kršćanskoj vjeri, ljubav će dobiti drugačiju funkciju: ljubav će biti, naime, ono ekstatično stanje koje jedino omogućuje doživljavanje potpunosti (Ljubljenje; Ljubezen [Ljubav]) (Kroflič 2005: 195-196).

Treća važna granična situacija je susret s transcendencijom, tj. pitanje postojanja Boga. Ova granična situacija dobija najveći značaj kod Kocbeka i Pilinszkoga koji su usko povezani sa kršćanskom vjerom i svjetonazorom koji proizlazi iz njega.

Osim traumatičnog iskustva drugog svjetskog rata koji se često pojavljuje i u lirskim tekstovima tih autora, Kocbek i Pilinszky su imali sličnih idejnih in-

${ }^{4}$ Funkciju motiva smrti i ulogu metaforike vezane sa smrću sam detaljno predstavila u Kálecz 2009: 62-68. 
spiracija: obojica su temeljito poznavali djelatnost kršćanskih egzistencijalista, pogotovo Kierkegaarda ${ }^{5}$ i francuskih personalista. Najvažniji njihov zajednički izvor inspiracije je svakako Simone Weil čije misli su izazvale veliku promjenu paradigme kod obojice autora. ${ }^{6}$

U pjesmama tih pjesnika vibrira snažna napetost između kršćanskog svjetonazora i svakodnevnog iskustva apsurda - stručna literatura, naime, obojicu autora karakterizira kao ,pjesnika sakrivenog Boga“ (Deus absconditus) ${ }^{7}-$ što oni u svojim djelima pokušavaju razriješiti. Ali vjera u Boga za njih je ujedno i izvor nade: sjedinjenje s transcendencijom je, naime, jedini izlaz iz apsurda (Edvard Kocbek: Jutro; Spreminjanje [Promjena]; János Pilinszky: Te gyözz le [Ti me pobjedi]; Éféli fürdés [Ponoćno kupanje]).

Za razliku od zapadnih egzistencijalističkih pisaca koji na razini poetičkih postupaka nisu donijeli previše novosti, dolazak srednjoeuropskih egzistencijalista je pored nove tematike značio novi period i na području pjesničkih postupaka i pjesničkog jezika.

Prvo, javlja se jaka predmetnost, tj. apstraktne, ontološke pojmove, otkrića i vlastite unutrašnje dispozicije nastoje izraziti pomoću originalnih i iznenađujućih slika uzetih iz konkretne stvarnosti. Ovaj pristup ima srodnosti sa novom stvarnošću poundovsko-eliotovskog ili rilkeovskog tipa - na što su književni povijesničari $^{8}$ ukazali u slučaju krugovaša, újholdaša, ali i u slučaju Kocbeka i Pilinszkoga - ali osim toga imaju i druge motive zbog čega se ne mogu izravno uvrstiti u tu tendenciju. Najtipičniji primjeri tih postupaka jesu Kocbekova pjesma Deček na drvesu [Dječak na drvetu], Mihalićeva pjesma Proljeće bez najmere i Pilinszkyjev Őszi vázlat [Jesenji pejzaž]. Ove pjesme čini posebnim to što se radi o pjesničkim pejzažima u kojima su prirodne pojave, razni elementi vidika zapravo refleksija unutrašnjih stanja lirskog subjekta.

Drugo, trojica pjesnika imaju mnogo dodirnih točaka i na području versifikacije. Rado upotrebljavaju slobodni stih, a njihov se pjesnički jezik znatno približava svakodnevnom govoru. Njihove su pjesme organizirane putem prijeloma redaka i raspoređivanjem teksta na semantičkoj osnovi. Ovi formotvorni elementi omogućuju da se čitatelj usredotoči na semantičke slojeve teksta (Kálecz 2009: 24-26). U slučaju Edvarda Kocbeka i Slavka Mihalića ove tvrdnje vrijede za njihovo cjelokupno životno djelo, dok Pilinszky u početku piše u vezanom stihu, a tek će se kasnije, u zbirci Nagyvárosi ikonok [Velegradske ikone] okrenuti slobodnom stihu.

${ }^{5} \mathrm{O}$ tome vidi Hankovszky (2006: 7).

${ }^{6}$ O tome vidi Kroflič (2005), odnosno Radnóti (1981) ili Tüskés (1996).

${ }^{7}$ O Kocbeku vidi npr. Hribar (2002: 503) i Svetina (2010: 28); o Pilinszkome vidi npr. Lörincz (2007: 507) i Szávai (2005: 87).

${ }^{8}$ O újholdašima i o Jánosu Pilinszkom vidi: http://mek.niif.hu/02200/02227/html/02/13. html (skinuto 24. 01. 2011.) i u Kulcsár Szabó (1993: 15); o krugovašima vidi: Detoni Dujmić (1995: 89); o Edvardu Kocbeku vidi: Pogačnik, Zadravec (1973: 501). 
U korpusu sve trojice pjesnika nalazimo vrlo kratke pjesme i/ili pjesme s relativno malim vokabularom. Stihovi pjesama semantički su znatno opterećenji, stoga ,semantički ritam“ - koji je se sastoji od zajedničkog utjecaja semantičkih slojeva i njihovih „suglasja“ - dobija poseban značaj (Kálecz 2009: 27-28) (Edvard Kocbek: Oba, Slavko Mihalić: Akord; János Pilinszky: Egy sírkőre [Na moj nadgrobni spomenik]).

Opis svijeta u koji je lirski subjekt bačen zrači pravi egzistencijalistički ambijent: u tom svijetu, naime, prevladava samoća, nesposobnost za komunikaciju i intimnost, te strah, tjeskoba i nemoć subjekta. Smrt je također dominantan element tekstova, i kao tema i kao simbol ili metafora. Radi postizanja ovih efekta sva trojica pjesnika predstavljaju sablasne vizije, halucinatorne slike koje - pogotovo u slučaju Mihalića i Kocbeka - zbog spajanja neobičnih slika i pojmova imaju i mnogo nadrealističkih crta (Edvard Kocbek: Mesečina [Mjesečina]; Sosed na oblaku [Susjed na oblaku]; Slavko Mihalić: Posljednji grad; János Pilinszky: Utószó [Pogovor]).

Naposlijetku, od brojnih tematskih sličnosti želimo detaljno predstaviti način tematiziranja apsurda u pjesništvu triju pjesnika.

U Kocbekovoj zbirci Zemlja još dominira ravnoteža između čovjeka i zemlje, empiričnog i mitičnog, te vlada sklad između egzistencije i esencije, premda se i tu pojavljuje strah, tjeskoba i slutnja raspadanja stvarnosti (Paternu 1999: 54). U kasnijim zbirkama sve snažnije prodire iskustvo apsurda: većina pjesama govori o izokrenutosti aktualnog društva, a i cijelog kozmosa - s izvjesnim brojem povijesnih aluzija.

Subjekt u početku očekuje spas od Boga - i u obliku individualne pomoći, i u obliku velikog konačnog spasenja svijeta apokaliptičke naravi (Jutro; V požgani vasi [U izgorjelom selu]; Spreminjanje [Promjena]). Dok neke pjesme, kao što i spomenute primjere, dominira čvrsta vjera i oduševljenje, tu vjeru gotovo uvijek prati skepsa i kolebanja, te doživljaj neuslišenosti. U drugim pjesmama je svijet sve češće predstavljen kao igralište hirovitih, zlih sila (Igra; Tema [Tama]; Blodnjak [Labirint]), bez ikakvog znaka postojanja višeg reda. Neke pjesme, međutim, idu sve do konstatiranja smrti Boga (Telo je tuja vlast [Tijelo je tuđe vlasništvo]). U ovom lirskom univerzumu, kako primjećuje i Ivo Svetina, Bog nipošto nije institucija vječnosti i beskonačnosti, nego postoji samo u čovjekovoj vjeri (Svetina 2010: 31).

Pilinszkyjevu liriku strukturira ista opozicija koju smo vidjeli u Kocbekovom pjesništvu. U prvoj fazi mađarski pjesnik očajno pokušava razriješiti svoje teodicejske sumnje koje dolaze iz doživljaja patnji, nepravdi i neuslišenosti. (Téli ég alatt [Ispod noćnog neba]; Gyász [Žalost]; Stigma; Panasz [Jadikovka]) Njegove su pjesme pokušaji artikuliranja vjerske pozicije koja može ostati autentična i u svjetlu apsurda. Ova se pozicija postepeno razvija u intertekstualnoj polemici s Camusom (vidi: Pilinszky 1982).

Polemiku Pilinszky zaključuje konkluzijom da je vjera, a time i prihvaćanje apsurdnosti svijeta zapravo još apsurdniji korak nego pobuna protiv apsurda, pa je zato i autentičniji (Pilinszky 1987: 82). Konačnom rješenju tih dilema je 
pridonio susret s idejama Simone Weil, nakon čega je pjesnik sklopio svojevrsnu primirbu s apsurdom. (A pokol hetedik köre [Sedmi krug pakla]; Most [Sada]; Vonzások közt [Među iskušenjima].) Pjesnik redefinira i ulogu patnje; prema novoj definiciji, smisao ljudskih patnji daje mogućnost ponovnog doživljavanja Isusovih muka (Pilinszky 1987: 83).

Patnja zauzima ključno mjesto i u Kocbekovom pjesništvu; prema čitanju Spomenke Hribar, slovenski pjesnik redefinira koncept svetoga. Dok je svetost prema tradicionalnom shvaćanju atribut Boga, Kocbek pojam spaja sa svim onim stvarima i bićima koji postoje, jedino zbog toga jer postoje - upravo zbog konačnosti, ranjivosti i tragičnosti njihovog bitka kojeg moraju podnijeti sami, bez pomoći transcendencije (Hribar 2002: 531).

Drugi ključni element Pilinszkyjeve promjene paradigme je potreba za poništavanjem individualnih crta subjekta, koji će omogućiti sjedinjenje čovjeka s transcendencijom (Kálecz 2009: 47). Istu tendenciju možemo opaziti i kod Slavka Mihalića. Dok Kocbek i rani Pilinszky nastoje naći izlaz iz apsurda, kod Mihalića prikazivanje apsurdnosti svijeta nije samo „dijagnoza“, nego od početka ima i druge funkcije. On naime svjesno traži mogućnosti da se suočava s apsurdom, da time poništava svoj subjekt, od čega očekuje „odmeđivanje“ - oslobađanje sebe i prekoračenje svojih granica, da bi na taj način postigao autentični bitak (Put u nepostojanje; Bih da se; Nokturno). Na osnovu toga možemo zaključiti da on ima slične koncepte o odnosu prema apsurdu (Kálecz 2009: 48-54) kao što i Camus (1990: 224-225).

S pravom možemo dakle zaključiti da srednjoeuropska egzistencijalistička lirika nije puko prepisivanje zapadnih egzistencijalističkih filozofa.

Za razliku od angažiranosti zapadnih istomišljenika, oni otvaraju ontološkoindividualističku perspektivu koju predstavljaju karakterističnim postupcima, kao što su primjerice uvođenje pjesničkog pristupa nove stvarnosti, depersonalizirajuće tendencije, stvaranje zatvorenog lirskog svijeta koji služi kao sredina za ontološku analizu lirskog subjekta i svijeta, te upotrebljavanje slobodnog stiha i jezika koji je vrlo blizak svakodnevnom govoru.

Pjesnici koji su pripadali ovoj tendenciji igrali su važnu ulogu u književnoj povijesti svojih naroda. Začeli su diskurs na koji su se mogle nadovezivati mnoge kasnije književne generacije - ne samo u pogledu tema i svjetonazora, nego i na razini pjesničkog jezika i drugih postupaka - definirajući time cijelo razdoblje kasne moderne, a djelomično i postmodernu u svojim zemljama.

\section{LITERATURA}

A magyar irodalom története. 1966. Vrijeme skidanja: 24. 01. 2011., izvor: Magyar Elektronikus Könyvtár, http://mek.niif.hu/02200/02227/html/02/13.html.

Ronald ARONSON, 2004: The Story of a Friendship and the Quarrel That Ended It. London: The University of Chicago Press. 
Albert CAMUS, 1990: Sziszüphosz mitosza. Budapest: Magvető.

Dunja DETONI DUJMIĆ, 1995: Krugovi. Zagreb: Zavod za znanost o književnosti.

Tamás HANKOVSZKY, 2006: Pilinszky János „esztétikájának“ időkoncepciójáról. Vrijeme skidanja: 17. 04. 2011., izvor: http://hankovszky.tamas.btk.ppke.hu/pb/idokonc.pdf.

Spomenka HRIBAR, 2002: Svetotvornost poezije. Ljubljana: Nova revija.

Orsolya KÁLECZ, 2008: Camus és Sartre egzisztencializmusa. ELTE. Diplomski rad. - -, 2009: Egzistencijalistički nemiri u Mihalićevom i Pilinszkyjevom pjesništvu. ELTE. Diplomski rad.

Terry KEEFE, 1974: French Existentialist Fiction: Changing Moral Perspectives. New York: Rowman \& Littlefield Publishers, Inc.

Edvard KOCBEK, 2006: Kisfiú a fán. Budapest: Széphalom Könyvmühely.

Albin KRALJ, 2005: Kocbek kot eden protagonistov slovenskega križarstva. Med smislom in skrivnostjo. Ur. Peter Kovačič-Peršin et al. Koper: Hyperion. 5-24.

Robert KROFLIČ, 2005: Kocbek kot pesnik in mislec ljubezni. Med smislom in skrivnostjo. Ur. Peter Kovačič-Peršin et al. Koper: Hyperion. 183-197.

Ernő KULCSÁR SZABÓ, 1993: A magyar irodalom története 1945-1991. Budapest: Argumentum.

Balázs LENGYEL, 1946: Babits után. Újhold 1/1, 1-8.

Csongor LÖRINCZ, 1982: Kép, szöveg és személytelenítés a transzcendens kommunikáció leépülésének lírájában. A magyar irodalom történetei: 1920-tól napjainkig. Ur. Mihály Szegedi-Maszák. Budapest: Gondolat. 507-519.

Ottó MAJOR, 1946: Az esztétikus problémája. Újhold 1/2, 129-134.

- -, 1948: Kegyetlen humanizmus. Újhold 3/1, 1-5.

Slavko MIHALIĆ, 1980: Izabrane pjesme. Zagreb: Matica Hrvatska.

Cvjetko MILANJA, 1991: Doba razlika. Zagreb: Stvarnost.

- -, 2003: Hrvatsko pjesništvo od 1950. do 2000. Zagreb: altaGAMA.

Irena NOVAK POPOV, 2003: Figure časa in večnosti v poeziji Edvarda Kocbeka. Med smislom in skrivnostjo. Maribor: Litera. 143-171.

Boris PATERNU, 1999: Poezija Edvarda Kocbeka. Od ekspresionizma do postmoderne. Maribor: Litera. 54-60.

János PILINSZKY, 1982: Krisztus és Sziszüphosz. Szög és olaj. Ur. István Jelenits. Budapest: Vigilia. 177-179.

--, 1987: Ars poetica helyett. Összegyüjtött müvei. Ur. István Jelenits. Budapest: Szépirodalmi Könyvkiadó. 80-83.

- -, 1987: Összegyüjtött müvei. Budapest: Szépirodalmi Könyvkiadó.

Jože POGAČNIK, Franc ZADRAVEC, 1973: Istorija slovenačke književnosti. Beograd: Nolit.

Leo POLLMANN, 1974: Sartre and Camus: Literature of Existence. New York: Frederick Ungar Publishing Co. 
Sándor RADNÓTI, 1981: A szenvedö misztikus (Misztika és líra összefüggése). Budapest: Akadémiai Kiadó.

Jean-Paul SARTRE, 1946: Existentialism is a Humanism. Vrijeme skidanja: 30. 10. 2008., izvor: http://www.theintellectualviewpoint.com/reading/existentialismisahumanism-sartre.pdf.

--, 1969: Mi az irodalom? Budapest: Gondolat.

--, 2006: A lét és a semmi: Egyfenomenológiai ontológia vázlata. Budapest: L’Harmattan.

György SOMLYÓ, 1947: Költők és utak. Újhold 2/1-2, 61-65.

Ivo SVETINA, 2010: Jezik, Bog, Pesem. Med smislom in skrivnostjo. Koper: Hyperion. $17-38$.

Miklós SZABOLCSI, 1946: Az antiintellektualizmus feltámadása. Újhold 1/1, 67-69.

Dorottya SZÁVAI, 2005: Bün és imádság. Budapest: Akadémiai Kiadó.

Tibor TÜSKÉS, 1996: Pilinszky János. Budapest: Kráter.

\section{EKSISTENCIALNO NAVDIHNJENA LIRIKA NA HRVAŠKEM, V SLOVENIJI IN NA MADŽARSKEM}

Razprava predstavlja srednjeevropsko eksistencialistično liriko petdesetih in šestdesetih let dvajsetega stoletja. Srednjeevropska smer je predstavljena v luči zahodnoevropske eksistencialistične književnosti. Medtem ko so se eksistencialisti na zahodu ukvarjali z družbenokritičnimi in kolektivističnimi vprašanji, so pri srednjeevropskih eksistencialistih prevladovala ontološka vprašanja, njihova interpretacija absurda pa je bila predvsem individualistična. Nadaljnja posebnost te smeri je, da se je namesto proze, ki je bila značilna za eksistencialiste, osredotočala predvsem na liriko, o kateri je Sartre menil, da ni primerna za uveljavljanje eksistencialističnih tem.

Razprava ob filozofskem kontekstu predstavlja tudi literarnozgodovinsko ozadje in posebno pozornost posveča pomenu časopisa Krugovi ter Újhold pri uveljavljanju eksistencialističnih idej in lirike nove predmetnosti T. S. Eliota ter Ezra Pounda. Nadalje predstavlja način, kako je novi diskurz, ki je ustvaril to smer, omogočil prekinitev z vsiljeno utilitaristično estetiko v književnosti in s tem nastanek suverene književnosti, ki temelji na samostojnih estetskih načelih.

$\mathrm{Na}$ koncu razprave so predstavljene tipološke podobnosti pesništva vodilnih pesnikov eksistencialističnega lirskega diskurza, Slovenca Edvarda Kocbeka, Hrvata Slavka Mihalića in Madžara Jánosa Pilinszkyja. Vzporednice najdemo ne le v temah, ampak tudi v pesniških sredstvih, npr. uveljavitev diskurza nove predmetnosti, različne metode depersonalizacije, ustvaritev zaprtega lirskega sveta, ki je hkrati prizorišče samoanalize lirskega subjekta, pogovornemu jeziku podoben pesniški jezik in svobodni verz.

Pesniki te smeri so ustvarili diskurz, h kateremu so se pridružile tudi kasnejše generacije, ne le glede zastopanih tem in svetovnega nazora, temveč tudi glede pesniškega jezika in pesniških instrumentov. Prav zaradi tega so ti pesniki močno vplivali ne le na pozno moderno, ampak tudi na postmoderno književnost. 